Section Editor Mitchell S.V. Elkind, MD, MS

\section{Teaching NeuroImages: \\ Neurogenic thoracic outlet syndrome}

Marco Luigetti, MD

Fioravante Capone, MD

Vincenzo Di Lazzaro, MD

Correspondence \& reprint requests to Dr. Di Lazzaro: vdilazzaro@rm.unicatt.it

Figure Right brachial plexus magnetic resonance neurography
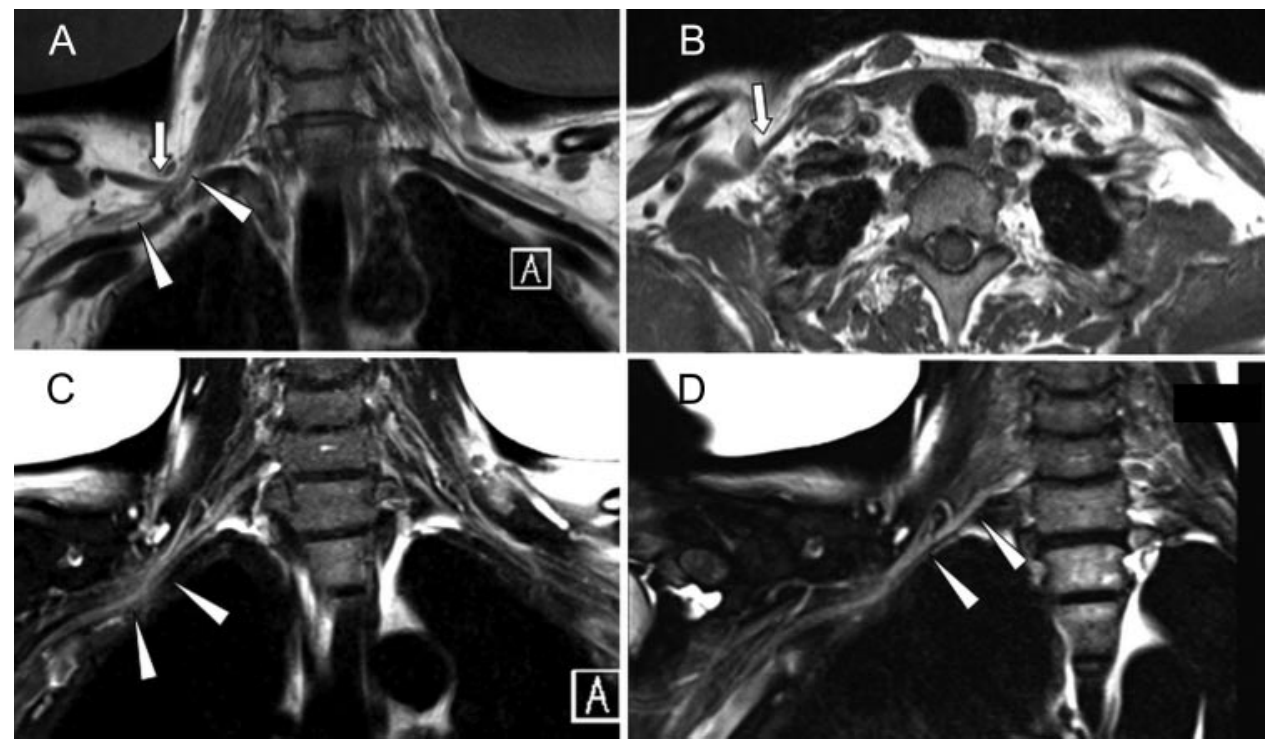

Coronal and axial T1-weighted images (A, B) and coronal fat-suppressed T2-weighted neurographic image (C) reveal a thick fibrous band (arrows in $\mathrm{A}$ and $\mathrm{B}$ ) causing distortion and edema of the right brachial plexus (arrowheads in $\mathrm{A}$ and $\mathrm{C}$ ). Oblique coronal fat-suppressed T2-weighted neurographic image (D) further illustrates a selective thickening of C8 root (arrowheads).

A 64-year-old man presented with a 5-month history of right neck and arm pain followed by progressive hand weakness. Cervical X-rays and MRI were normal. EMG disclosed lower trunk brachial plexopathy. Magnetic resonance (MR) neurography revealed right brachial plexus distortion with thickening of the $\mathrm{C} 8$ root caused by a fibrous band (figure, A-D). The patient refused surgery.

Thoracic outlet syndrome (TOS) refers to symptoms caused by neurovascular bundle compression at the transition between the neck and axilla. ${ }^{1}$ Many factors can predispose to neurogenic TOS, including cervical ribs, anomalous first ribs, and congenital narrow scalene triangles. ${ }^{1}$ If standard X-rays prove normal, MR neurography may be useful in identifying the nature and site of the lesion. ${ }^{2}$

\section{AUTHOR CONTRIBUTIONS}

Drafting/revising the manuscript for content, including medical writing for content; study concept or design; analysis or interpretation of data; acquisition of data; study supervision or coordination: Dr. Luigetti, Dr. Capone, Prof. Di Lazzaro.

\section{REFERENCES}

1. Sanders RJ, Hammond SL, Rao NM. Thoracic outlet syndrome: a review. Neurologist 2008;14:365-373.

2. Ferrante MA. Brachial plexopathies: classification, causes, and consequences. Muscle Nerve 2004;30:547-568. 


\section{Neurology}

Teaching NeuroImages: Neurogenic thoracic outlet syndrome

Marco Luigetti, Fioravante Capone and Vincenzo Di Lazzaro

Neurology 2012;79; e11

DOI 10.1212/WNL.0b013e31825f0511

This information is current as of July 9, 2012

\section{Updated Information \&} Services

\section{References}

Subspecialty Collections

Permissions \& Licensing

Reprints including high resolution figures, can be found at:

http://n.neurology.org/content/79/2/e11.full

This article cites 2 articles, 0 of which you can access for free at: http://n.neurology.org/content/79/2/e11.full\#ref-list-1

This article, along with others on similar topics, appears in the following collection(s):

EMG

http://n.neurology.org/cgi/collection/emg

MRI

http://n.neurology.org/cgi/collection/mri

Information about reproducing this article in parts (figures,tables) or in its entirety can be found online at:

http://www.neurology.org/about/about_the_journal\#permissions

Information about ordering reprints can be found online:

http://n.neurology.org/subscribers/advertise

Neurology ${ }^{\circledR}$ is the official journal of the American Academy of Neurology. Published continuously since 1951, it is now a weekly with 48 issues per year. Copyright Copyright (? 2012 by AAN Enterprises, Inc.. All rights reserved. Print ISSN: 0028-3878. Online ISSN: 1526-632X.

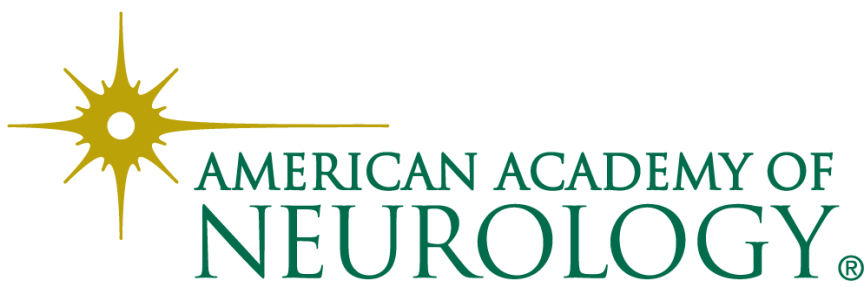

